\title{
REVITALIZATION OF PASAMBAHAN MANJAPUIK MARAPULAI AS A PART OF MAINTAINING EFFORTS OF MINANGKABAU CULTURE
}

\author{
Srimaharani Tanjung \\ Institut Pendidikan Tapanuli Selatan, Padangsidimpuan, INDONESIA \\ CORRESPONDENCE: $\$ nani_tanjung21@yahoo.com

\begin{abstract}
The current of increasingly strong modernization has caused the local wisdom of a culture to be eliminated and replaced with a new form of habit instantly. This condition causes humans escape beyond the scope of their original tradition, and cause them become a crisis of identity and cultural breakdown. This paper aims to show the importance of revitalizing the tradition of Pasambahan manjapuik marapulai as part of efforts to preserve the Minangkabau culture. This type of research is descriptive qualitative. Sources of data obtained from field observations and interviews with informants and study documentation. The results showed that in order to revitalize the tradition of Pasambahan manjapuik marapulai, this can be done through three (3) stages, namely: activating, managing and inheritance. Activating can be done by socializing Minangkabau culture through education, re-functioning the traditional process, and forming a youth organization. Managing can be done by managing training time, promoting and involving youth in a series of events. Inheritance can be done through radio broadcasting, airing custom shows on local television, posting cultural advertisement and inventory.
\end{abstract}

Keywords: revitalization, oral tradition, Pasambahan manjapuik marapulai

\section{INTRODUCTION}

The Minangkabau people in Sungai Geringging Subdistrict community are still maintain the traditions in the middle of the Pariaman community compared to other Minangkabau sub-ethnic groups in the province of West Sumatra. The Sungai Geringging Subdistrict community are still maintains the customs of Manjapuik Marapulai in wedding ceremony and considers the customs to be able to regulate people's lives from time to time and from generation to the next generation. However, over the time, the Manjapuik Marapulai tradition seems to have been eroded by the development of times. This is due to the increasing number of people who no longer consider that costum is a necessity.

This condition is marked by the number of Minangkabau youths leaving their hometown to find work for their survival. In addition, the mingling of the native Minangkabau community with people outside Minangkabau itself, such as Malay, Mandailing, Angkola, and other tribes, makes the custom mix or package it simpler in accordance with the agreement between the two families implementing the event. Such a situation will make the meaning of costum in the tradition diminished or even disappear altogether marked by the reduction in the implementation of the customary procession, especially because the 
community is more concerned with the nominal value given to the prospective bridegroom or also called uang japuik compared to implementing costum in a manner intact. This can be illustrated when they do the pasambahan. If in the past the pasambahan was carried out by several people from each party and carried out in a relatively long period of time, then now it is generally only carried out by one spokesperson as only representatives from each party both from the anak daro and marapulai and also carried out with a relatively in short period of time.

If this condition continues to be implemented, indirectly the pasambahan of the Manjapuik Marapulai will disappear and be replaced by only a ceremonial of giving money. The position of the addition in carrying out the custom event is of great value, because the art of communication will be clearly seen through this pasambahan. Djamaris (2002) states that pasambahan is speech used in traditional ceremonies that are arranged, organized and rhythmic, and are associated with tambo and by stating intentions, respect, signs of greatness, and signs of glory. In pasambahan the language used are polite and high-quality that parable and full of cultural values. The shifting of oral tradition in wedding ceremonial occurs when a community collectively abandons the traditional habits that have been taking place from one generation to another. Traditions that have begun to be abandoned by their communities in daily life need to be taken measures and preventive measures so that oral traditions that have been taking place in the community in the form of revitalizing the oral tradition. The importance of revitalizing oral traditions as an effort to transmit from one generation to another in the form of continuous revitalization. To maintain this continuity of oral tradition, researchers need to create a revitalization model to revive the tradition and to function cultural values and norms in the community, Sibarani (2012). As mentioned in the previous opinion, the revitalizing the oral tradition at Minangkabau marriage ceremony conceptualized there has been a shift in the oral tradition in people's lives. So, as an effort to revitalize, the process of maintaining of oral traditions in Minangkabau wedding is needed, so that the oral tradition is not lost.

\section{METHODOLOGY}

The study was conducted in Sungai Geringging District, Pariaman Regency. Descriptive qualitative method used in this study. Data sources used are primary data and secondary data. The primary data of this study were obtained directly when the implementation of traditional wedding ceremonies were carried out and for secondary data the researchers obtained them in the form of text, pictures and sounds. Research data were collected by conducting in-depth interviews with informants, conducting direct observations, documenting them with audio and video recording devices, and conducting documentation studies that the authors obtained from the field. From the data 
obtained by the author using the technique of data analysis by Miles, Huberman, \& Saldana, (2014), namely the activities in qualitative data analysis are carried out interactively and continue continuously until completion, so that the data is saturated.

Activities in analyzing qualitative data, namely: (1) Gathering all activities carried out in the Manjapuik Marapulai event documented through camcorders and mobile phones as primary data as well as the results of the flow record and the results of the interview recordings. Meanwhile for secondary data, the writer collects information from statistical data, on-line data search, post-data flow scripts that the author obtained from one informant, as well as the results of discussions that have been carried out before and after the implementation of the Manjapuik Marapulai event. (2) Data reduction by sorting, categorizing, and making abstraction notes from field notes, interviews and documentation. (3) Presentation of data throughout the series of Manjapuik Marapulai events in the form of narrative texts that the writer presents systematically or simultaneously so that the data that has been obtained can answer the problem under the study. (4) Drawing conclusions or verification in a descriptive form.

\section{RESULTS AND DISCUSSION}

Revitalization is a process, method, or act to revive or revitalize any program of activities in a community that was previously powerless. Revitalization can also be interpreted as a way to revive vitality. Actually revitalization means to make an action or become vital, while the word vital has a very important meaning for human life. In terms of revitalizing the culture, concrete steps must be taken to maintain that culture so that it will continue to live in the midst of the community, even if it has to oppose the current development of the age which will increasingly leave its original identity. Did not rule out the possibility of the influence of western culture or outside culture that is increasingly being found more and more at social events, one of them is in terms of marriage.

Deterioration of local culture can be influenced by the mindset of people who think that western culture or outside culture is a modern culture that must be followed, so that the community can be considered to be people who have modern behavior and do not behave in an old-fashioned manner. But if this kind of mindset continues to be allowed to indirectly close the possibility of a decline or even the extinction of the local culture itself. Factors that determine the vitality of culture and customs are extinct, as an indicator of threat in revitalization processes according to Grenoble \& Whaley (2006) adapted from Whaley (2003), Kinkade (1991), and Wurm (1998) the threat category is:

1) Safe, a tradition is considered safe when the generation still uses tradition in daily life,

2) Risk, if a tradition is used by a limited number of people in the same area,

3) Disappeared, customs and culture whose usage is decreasing the number of speeches, so that the regeneration process of the community of indigenous users and traditions 
from one generation to the next decreases or even disappears,

4) Dying is said to be almost dead if the number of indigenous users decreases the number of speakers of oral tradition, so that it is no longer passed down to the next generation,

5) It is almost extinct, if only a small number of language users,

6) Extinct, if a custom and culture which no longer has a speaker, then the customs and culture will become extinct.

This is where the important role of revitalization in arousing cultural passion so that culture can survive from one generation to the next. As long as the culture can be maintained by the community, so that the large influence of outside culture will be difficult to change even to influence the local culture itself. Manjapuik Marapulai tradition is closely related to the understanding of moral values which are held based on rules that originate from the traditional teachings of the local community. In accordance with the philosophy of the Minangkabau people who become the basic reference and guidelines that govern the lives of the Minangkabau people in their daily behavior.

The basic nature of the custom of the Minangness is in accordance with the proverb as follows:

Adat babuhue sintak
Syarak babuhue mati

Buhue means knot or bond, while sintak means easy to loosen or tighten. Buhue sintak means customary bond or a bond that can be opened to accept new developments in accordance with the consideration or logic of the Minangkabau people based on consultation and consensus of traditional leaders, such as: ninik mamak, panghulu, cadiak pandai, bundo kanduang and pamudo. Conversely it can also be tightened or tightened to something customary rules that are starting to loose. Here it can be seen that Minangkabau costum has a flexible nature that regulates all customary behaviors in the community. Syarak can be interpreted as the teachings of Islam or Islamic law. Babuhue mati means bonding with a square knot. In the case the square not is the teachings of Islam are an absolute. Sibarani (2012) states that there are three components in revitalizing an oral tradition, namely: First, reviving or reactivation.

The first component is intended for oral traditions that have become extinct or have no function at all in the community to be revived, while activation is defined as oral traditions that are still alive but no longer functioned as part of people's lives to be reactivated. In terms of revitalizing the Manjapuik Marapulai tradition in Sungai Garingging District, this tradition is still alive and continues from the past until now, but there is a slight difference in the process of carrying out the tradition unlike before, such as using quite a long time while now prioritizing efficiency relatively short period of time.

To revitalize the Manjapuik Marapulai tradition, relating to the first component, it can be done in several ways, including: 
1)Disseminating Minangkabau culture through education

Education is one way to introduce Minangkabau culture to its people from an early age, which starts at the elementary school level up to junior high school level. One of the subjects at the elementary and junior high school level is based on local content, namely "Budaya Alam Minangkabau (BAM)" or the culture of Minangkabau nature. At this education level, it is about the culture found in the Minangkabau, including the proverb, the pasambahan, the Minangkabau moral teachings and so forth. It is better to deliberate the doers or artists to complete the teaching. Lubis (2019) the advantages of collaboration result the synergic and integrated method because learning becomes more real. In addition, it is also one of the efforts to revitalize the oral traditions of the region which are now is endangered. The young generation has the right to get knowledge about the way of life and socializing in the community as well as knowledge about how to treat the surrounding environment.

2)Re-functioning the process of the Manjapuik

\section{Marapulai tradition}

In some cases in Pariaman areas there has been a change of view in the community which is more concerned with uang japuik rather than the traditional process of picking up the marapulai (groom). This point of view makes the process of Manjapuik Marapulai just merely delivering uang japuik and other requirements, without making pasambahan as a necessity. This is where the role of local traditional leaders to straighten out and refunction the proper view of the Manjapuik Marapulai tradition. The revitalization should be recorded through audio-video due to document the performance of is able to document the the Manjapuik Marapulai tradition. Lubis et al. (2018) state that it is matter to study about performance because it covered human feeling, idea, and thought not only in literal way but also in non-literal way.

3) Form a youth organization

This youth organization is intended to instill a spirit of love for Minangkabau culture, one of them is about pasambahan and its procedure. Many Minangkabau youth do not understand their culture, they only focus on education and employment. It is difficult to think if this is done by every young man in that society, of course there would be no more inheritance of traditions especially in doing pasambahan. Though this pasambahan is need to be done in traditional events. This is where the important role of youth organizations, which provides training pasambahan and Minangkabau costum, because basically this pasambahan will not come alone without having to be studied, but it must be studied, familiarized and applied.

Second, management. The second component is related to the needs of the 
community, especially those governing oral traditions in a community today. To revitalize the Manjapuik marapulai tradition, related to the second component, it can be done in several ways, including:

1) Manage training time for youth organization members

To instill a disciplined spirit is indeed difficult to do, but if there is cooperation between youth, parents, and coaches, it will be able to foster a disciplined personality in member of youth organization. The Proper time management is become a priority to achieve the goals of the organization and can run well.

2) Promoting to the community

Society is a person who needs to keep the tradition alive in the midst of the community. To promote culture, especially regarding pasambahan, it can be done by holding competitions related to custom, including the pasambahan. By empowering this youth organization it is expected to be able to introduce and maintain the continuity of costum in the midst of society.

3) Involving youth in marriages ceremonial, especially in Manjapuik Marapulai events.

Generally in the Manjapuik Marapulai event is held by those people inside the event, they are older people, while young people prefer to sit outside the room. This Such conditions must be changed, because by placing them in the room will affect their cultural knowledge indirectly. To some extent they will know about the procedures for the implementation of Manjapuik Marapulai and see the process of pasambahan that held in that event.

Third, inheritance of oral tradition. The third component is related to the inheritance system of oral traditions in the social community. To revitalize the Manjapuik Marapulai tradition, relating to the third component, it can be done in several ways, they are:

1)Radio broadcasting about Minangkabau customs and culture.

2) The broadcasting of custom programs through local television media.

3) The Installation of Minangkabau cultural advertisement. The three ways that the authors mentioned above relate to the way of inheritance that can be seen by the general public as cultural users in a community in this case is the Minangkabau community that is carried out consistently or continuously.

4)Inventarisation. The way to inherit oral tradition in the fourth part is related to recording or collecting data about the process of implementing the Manjapuik Marapulai tradition, so that the data can be collected and stored properly as a cultural archive.

The entire method of the manjapuik revitalization model for the start of the Minangkabau marriage custom, can be seen in the following figure 1 : 


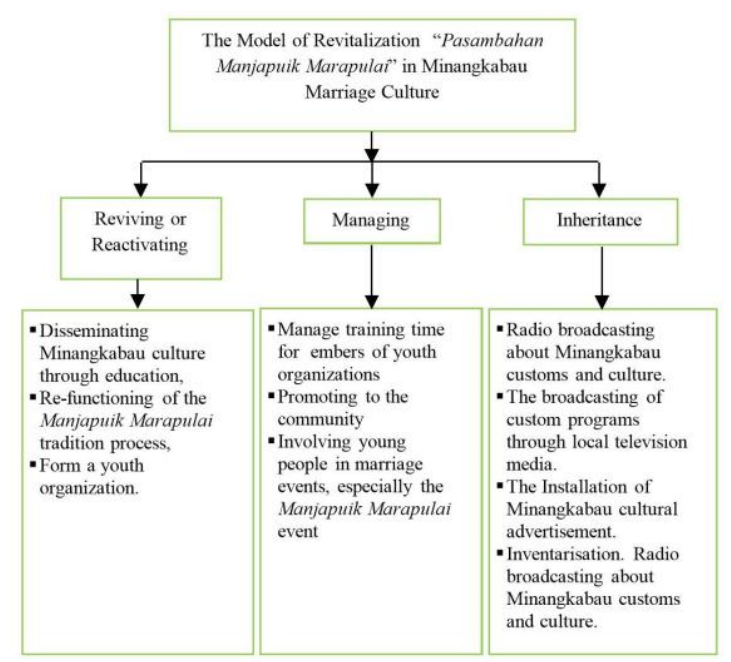

Figure 1. Manjapuik revitalization model for the start of the Minangkabau marriage custom

\section{CONCLUSION}

Manjapuik Marapulai tradition is closely related to the understanding of moral values which are held based on rules that originate from the traditional teachings of the local community. In accordance with the philosophy of the Minangkabau people who become the basic reference and guidelines that govern the lives of the Minangkabau people in their daily behavior.

The revitalization model in the Manjapuik Marapulai tradition can be classified into three components, namely: activating, managing, and inheritance. In connection with the first component, it can be done by: promoting Minangkabau culture through education, refunction the process of Manjapuik Marapulai tradition, and forming a youth organization. Furthermore, for the second component can be done by: Managing training time for members of youth organizations, Promoting to the community, and Involving young people in marriage events, especially in the Manjapuik Marapulai event. The last component can be carried out by: through radio broadcasting about Minangkabau customs and culture, through broadcasting custom programs through local television media, posting advertisements for Minangkabau cultural and inventarisation. With a note for the sake of the continuation of the Minangkabau cultural inheritance must always be done consistently and continuously.

\section{Disclosure statement}

No potential conflict of interest was reported by the authors.

\section{Notes on contributors}

Srimaharani Tanjung had finished her Doctoral program at Linguistic Doctoral Program in Universitas Sumatera Utara (North Sumatera University) through her dissertation entitled: Tradisi Lisan Pasambahan Manjapuik Marapulai dalam Konteks Upacara Adat Perkawinan Minangkabau di Sungai Garingging, Pariaman. The promotor was Prof. Tengku Silvana Sinar, M.A., Ph.D and the co-promotor were Prof. Dr. Ikhwanuddin Nasution, M.Si and Drs. Muhammad Takari, M.Hum., Ph.D. For her master degree, she had finished her study at Linguistik Terapan Bahasa Inggris Pascasarjana Universitas Negeri Medan (English applied Linguistic program in United State of Medan University). Previously, she had finished her Bachelor Degree at Universitas Bung Hatta Padang. She has been a fulltime lecture at Yayasan Institut Pendidikan Tapanuli Selatan (IPTS) Program Studi Pendidikan Bahasa Inggris.

\section{REFERENCES}

Edwar Djamaris. (2002). Pengantar Sastra Lisan Minangkabau. Jakarta: Yayasan Obor Indonesia.

Grenoble, L. A., \& Whaley, L. J. (2006). Saving Languages: An Introduction to Language Revitalization. New York: Cambridge 
University Press.

Lubis, T. (2019). Learning Nandong in schools as a medium to inform the Simeuluenese local wisdom: An anthropolinguistics approach. Studies in English Language and Education, 6(2), 262-272.

Lubis, T., Sibarani, R., Lubis, S., \& Azhari, I. (2018). The Performance of Nandong in Simeulue Island. International Journal of Research and Review, 5(12), 283-289. https://doi.org/inrein.com/10.4444/ijrr.1002/ 886

Miles, M. B., Huberman, A. M., \& Saldana, J. (2014). Qualitative Data Analysis: A Methods Sourcebook. Thousand Oaks: SAGE Publications, Inc.

Sibarani, R. (2012). Kearifan Lokal: Hakikat, Peran, dan Metode Tradisi Lisan. Jakarta: Asosiasi Tradisi Lisan (ATL).

Edwar Djamaris. (2002). Pengantar Sastra Lisan Minangkabau. Jakarta: Yayasan Obor Indonesia.

Grenoble, L. A., \& Whaley, L. J. (2006). Saving Languages: An Introduction to Language
Revitalization. New York: Cambridge University Press.

Lubis, T. (2019). Learning Nandong in schools as a medium to inform the Simeuluenese local wisdom: An anthropolinguistics approach. Studies in English Language and Education, 6(2), 262-272.

Lubis, T., Sibarani, R., Lubis, S., \& Azhari, I. (2018). The Performance of Nandong in Simeulue Island. International Journal of Research and Review, 5(12), 283-289. https://doi.org/inrein.com/10.4444/ijrr.1002/ 886

Miles, M. B., Huberman, A. M., \& Saldana, J. (2014). Qualitative Data Analysis: A Methods Sourcebook. Thousand Oaks: SAGE Publications, Inc.

Sibarani, R. (2012). Kearifan Lokal: Hakikat, Peran, dan Metode Tradisi Lisan. Jakarta: Asosiasi Tradisi Lisan (ATL). 